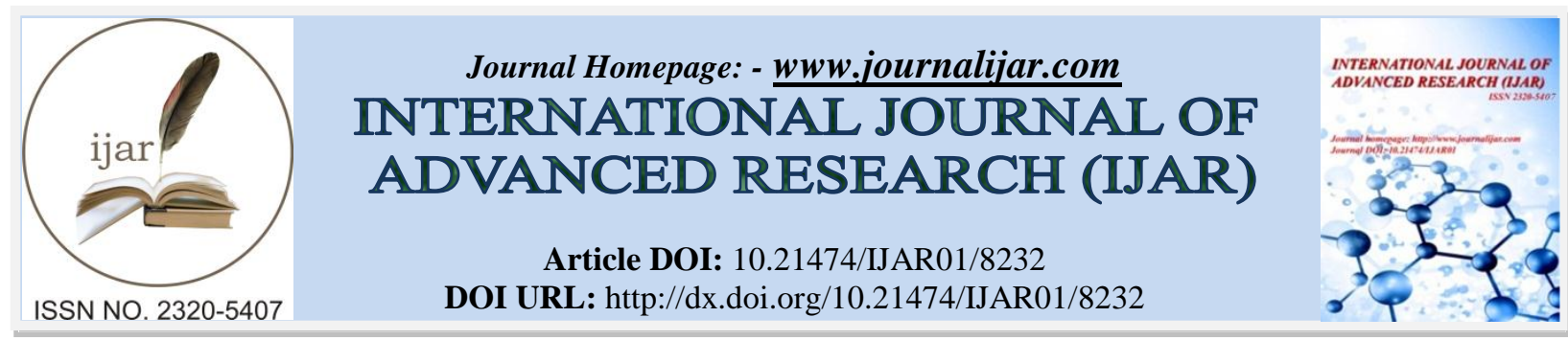

RESEARCH ARTICLE

\title{
ANTIOXIDANT ACTIVITY OF THE EXTRACTS OF PLANTS OF THE FLORA OF THE NORTH CAUCASUS.
}

\section{Pozdnyakov DI, Adzhiahmetova SL, Chervonnaya NM, Zolotych DS, Dajronas ZV., Vernikovskij VV, Kharchenko II, Pozdnyakova AE. And Lyakhova NS. \\ Pyatigorsk Medical and Pharmaceutical Institute, a branch Volgograd State Medical University, Pyatigorsk, Russia (357532, Pyatigorsk, av. Kalinina 11).}

\section{Manuscript Info}

\section{Manuscript History}

Received: 18 October 2018

Final Accepted: 20 November 2018

Published: December 2018

Keywords:

oxidative stress, antiradical activity, plant extracts.

\begin{abstract}
Background: A significant increase the number of diseases associated with the development of oxidative stress dictates the need to find effective and safe agents with antioxidant activity. High efficiency and safety combine means of plant origin, which makes them promising objects for studying antioxidant properties. Thus, the aim of the study was to evaluate the antioxidant activity of plant extracts by in vitro tests.

Materials and methods: The antioxidant properties of 9 plant extracts in the concentration range of 62.5-1000 $\mu \mathrm{g} / \mathrm{ml}$, obtained from: Cucurbita pepo L., Juglans nigra L., Tagetes patula L., Rudbeckia laciniata L., Grossularia reclinata (L.) Mill., Ribes nigrum L., Rubus caesius L., Lysimachia punctata L., Morus alba L. was studied. Model systems of free radical generation included of DPPH-radical, superoxide, hydroxyl and nitrosyl radicals. Additionally, the chelating properties of the test extracts were studied. The results were processed statistically with the calculation of the $\mathrm{IC}_{50}$.

Results: From 9 test extracts 3 have pronounced antioxidant properties - extracts of mulberry, pumpkin and walnut. In model systems, these objects interfered with the generation of DPPH radical, superoxide, hydroxyl and nitrosyl radicals, and also exhibited chelating activity, which was comparable to that of referents.

Conclusion: The study showed the prospects of further study of extracts of mulberry, pumpkin and walnut as a means with antioxidant properties, and also demonstrated the possibility of using these objects to correct oxidative stress.
\end{abstract}

Copy Right, IJAR, 2018,. All rights reserved.

\section{Introduction:-}

At the present stage of the development of society, a person is constantly subject to the action of unfavorable factors, which adversely affect his general-functional state [1]. The resulting disadaptation leads to the development of new or exacerbation of existing diseases, which worsens the quality of life and contributes to a decrease in the overall life expectancy of the population. [2] It is established that one of the leading links that causes disadaptation is the development of oxidative stress. Induction of oxidative stress occurs as a consequence of the redox imbalance,

\section{Corresponding Author:-Pozdnyakov DI.}


between the formation of active oxygen / nitrogen forms (ROS) and their inactivation by the antioxidant defense system [3]. ROS formed in the cell constantly and, in general, perform the function of cellular signaling and are responsible for the regulation of the vascular tone of the microcirculatory bed. The main sources of endogenous ROS are the reactions of oxidative phosphorylation in the mitochondrial respiratory chain, peroxisomes. In addition, the ROS can generate cytochrome $\mathrm{P}_{450}$ in the detoxification of xenobiotics processes [4].

Hyperproduction of ROS leads to the loss of their physiological functions, and highly reactive radicals initiate damage to cellular structures, mainly DNA, proteins and membrane lipids. The most damaging ability with respect to cells is possessed by: superoxide radical, hydroxyl radical, peroxide, and reaction product of superoxide radical and nitrite-peroxonitrite [5]. The system of antioxidant protection, which includes enzymatic (SOD, catalase, glutathione peroxidase) and non-enzymatic components (vitamins $\mathrm{C}$ and $\mathrm{E}$, glutathione, $\beta$-carotene, coenzyme $\mathrm{Q}_{10}$ ) can inhibit the action of excess ROS on the cell structure [6]. The antioxidant system of the cell is effective against the negative effect of endogenous ROS (mainly mitochondrial genesis) and forceful oxidants, xenobiotics, etc. on the body. [7]. This fact makes it expedient to use agents that have an antioxidant properties to correct oxidative stress.

It is known that medicinal plants play an important role in the health system of developing countries in order to meet the needs of the population for primary health care. The popularity of natural phytocomplexes is associated with their availability, high therapeutic efficacy and low toxicity [8]. Plant objects contain many metabolites with different types of biological activity, including antioxidant [9]. Thus, it is relevant to search for funds that have antioxidant activity among natural objects.

\section{Materials and methods:-}

The objects for the study were total extracts - extracts from the bark of Juglans nigra L (black walnut).; Inflorescence of: Tagetes patula L.(marigold), Rudbeckia laciniata L. (rudbeckia); Leaves: Grossularia reclinata (L.) Mill. (gooseberry), Ribes nigrum L. (currant), Rubus caesius L. (blackberries), Morus alba L (mulberry).; Herb: Lysimachia punctata L.(loosestrife); Fruitage: Cucurbita pepo L. (pumpkin).

\section{Preparation of the test extracts Juglans nigra bark extract}

The crushed black walnut (Juglans nigra L.) bark was extracted with ethanol at a ratio of 1:4 for 2 days. The resulting extract was settled at a temperature of $8-10^{\circ} \mathrm{C}$ for 2 days, filtered through paper filter and evaporated on a rotary evaporator under vacuum at a temperature of $50^{\circ} \mathrm{C}$ to $1 / 5$ of the initial volume.

Extracts from the remaining investigated objects were obtained by extracting the raw material with ethanol $40 \%$ or $70 \%$ in a water bath in a flask with a reflux condenser (extraction rate - 3, duration - 1 hour).

The antiradical activity of the extracts was evaluated in the concentration range: $1000 \mu \mathrm{g} / \mathrm{ml} ; 500 \mu \mathrm{g} / \mathrm{ml} ; 250 \mu \mathrm{g} /$ $\mathrm{ml} ; 125 \mu \mathrm{g} / \mathrm{ml} ; 62.5 \mu \mathrm{g} / \mathrm{ml}$. The antiradical properties of the test extracts were determined by various in vitro model ROS-generation test systems: DPPH-radical, superoxide, hydroxyl and nitrosyl radicals. Also chelating properties of the evaluated extracts were studied.

\section{DPPH - scavenging activity}

The Mensor method was used as a basis for the study of DPPH-antiradical activity [10]. To 0.5 ml of methanol 0.4 $\mathrm{mM}$ DPPH solution, $1 \mathrm{ml}$ of the solution of the test extracts was added in the range of estimated concentrations and incubated at room temperature for 30 minutes. As a reference substance, ascorbic acid was used in similar concentrations. After the indicated time interval, the absorbance of the samples was recorded at a wavelength of 518 $\mathrm{nm}$ against pure methanol. A solution of DPPH in methanol was taken as a positive control $\left(\mathrm{A}_{0}\right)$. The percentage inhibition of DPPH radical formation was calculated from formula (1):

$$
\% \text { inhibition }=\mathrm{Ax} / \mathrm{A} 0 * 100 \text {, where }
$$

$\mathrm{Ax}$ - is the optical density of the sample sample of the extract; $\mathrm{A}_{0}$ - is the optical density of the positive control sample.

\section{Hydroxyl radical - scavenging activity}

The method is based on the spectrophotometric detection of a colored complex of degradation products of 2deoxyribose with thiobarbituric acid [11]. The hydroxyl radical was generated in a Fenton reaction $(0.1 \mathrm{ml}$ of a 2.8 
$\mathrm{mM}$ deoxyribose solution $+0.1 \mathrm{ml}$ of a $0.1 \mathrm{mM}$ EDTA $+0.1 \mathrm{ml} 0.1 \mathrm{mM}$ ascorbate solution $+0.1 \mathrm{ml}$ phosphate buffer $(\mathrm{pH} \mathrm{7,4)}$ To the resulting model mixture, $1 \mathrm{ml}$ of the solution of the test extracts was added in the range of the concentrations to be evaluated.Incubated for 60 minutes at $370 \mathrm{C}$. Then, $1 \mathrm{ml}$ of a $2.8 \%$ solution of trichloroacetic acid and $1 \mathrm{ml}$ of $1 \%$ thiobarbituric acid solution was added to the medium, water bath $\left(100^{0} \mathrm{C}\right)$ for 20 minutes After cooling, the optical density of the samples was measured at a wavelength of $532 \mathrm{~nm}$ against Positive control was the generation medium of the hydroxyl radical without addition of the extract under study, and ascorbic acid was used as a reference substance at similar concentrations.

\section{Superoxide radical - scavenging activity}

The basis of the analysis was the method described by Winterbourn [12], based on the photoconvertion of riboflavin reaction. The incubation medium contained $0.1 \mathrm{ml}$ of the solution of the extracts studied in various concentrations + $0.1 \mathrm{ml}$ of a $1.5 \mathrm{mM}$ solution of nitro-blue tetrazolium $+0.2 \mathrm{ml}$ of $0.1 \mathrm{M}$ EDTA $+0.05 \mathrm{ml}$ of $0.12 \mathrm{mM}$ riboflavin +2 solution, $55 \mathrm{ml}$ of phosphate buffer $(\mathrm{pH} 7.4)$. The resulting mixture was incubated for 5 minutes at $25^{\circ} \mathrm{C}$. The absorbance of the samples was measured at $560 \mathrm{~nm}$ against air. As a reference substance, ascorbic acid was used in similar concentrations. Positive control was the incubation medium without adding the extract under study. The percentage inhibition was calculated by the formula 1 .

\section{Nitrosyl radical - scavenging activity.}

The analysis was based on the ability of sodium nitroprusside in a water solution disintegrate with generating a nitrosyl radical [13]. Analysis: $2 \mathrm{ml}$ of a $10 \mathrm{mM}$ sodium nitroprusside solution $+0.5 \mathrm{ml}$ phosphate buffer $(\mathrm{pH} 7.4)+$ $0.5 \mathrm{ml}$ of the solution of the test extracts were added to the cuvette at various concentrations. The resulting mixture was incubated at $25^{\circ} \mathrm{C}$ for 15 minutes. After a period of incubation, $0.5 \mathrm{ml}$ of Griess reagent was added to the medium, incubated for 30 minutes at room temperature. The absorbance of the samples was measured at $546 \mathrm{~nm}$. As a reference substance, ascorbic acid was used in similar concentrations. The percentage of inhibition of the nitrosyl radical was calculated from formula (2):

$$
\% \text { inhibition }=\mathrm{Ax} / \mathrm{A} 0 * 100 \text {, where }
$$

$\mathrm{Ax}$ - is the optical density of the sample before the addition of the Griess reagent; $A_{0}$ - is the optical density of the sample after addition of the Griess reagent

\section{Iron-chelating activity}

The chelating properties of the test extracts were evaluated by the $o$-phenanthroline method proposed by Benzie \& Strain [14]. The incubation medium consisted of $1 \mathrm{ml}$ of $0.05 \%$ methanol solution of $o$-phenanthroline $+2 \mathrm{ml}$ of iron (II) chloride $(200 \mu \mathrm{M})+2 \mathrm{ml}$ of various concentrations of the test extracts. The resulting mixture was incubated for 10 minutes at room temperature. The absorbance of the samples was measured at $510 \mathrm{~nm}$. EDTA (reference metal chelator) was used in similar concentrations. Positive control was the incubation medium without the addition of the test extracts. The percentage inhibition was calculated by the formula 1.

\section{Total flavonoids}

The total content of flavonoids in the extract was determined by reaction with aluminum chloride [15]. The reaction mixture contained $1 \mathrm{ml}$ of the solution of the studied extract (1:10) in various concentrations $+0.5 \mathrm{ml}$ of a $1.2 \%$ solution of aluminum chloride $+0.5 \mathrm{ml}$ of a saturated solution of potassium acetate. The medium was incubated for 30 minutes. at room temperature, and the absorbance of the samples was measured at $415 \mathrm{~nm}$. The total content of flavonoids was expressed in terms of standart sample $(\mathrm{mg} / \mathrm{g})$.

\section{Stastical methods:-}

The obtained data during the experiment were statistically processed. In the work we used software packages of statistical analysis MS Excel v.10 and «STATISTICA 6.0». The $\mathrm{IC}_{50}$ value was calculated by the probit analysis method.

\section{Results:-}

Estimating the superoxide radical (Fig. 1), scavenging activity revealed that the greatest inhibitory ability with respect to this radical was the extract of mulberry $\left(\mathrm{IC}_{50}=14.8 \mu \mathrm{g} / \mathrm{ml}\right)$, pumpkin $\left(\mathrm{IC}_{50}=20.2 \mu \mathrm{g} / \mathrm{ml}\right)$, walnut $\mathrm{IC}_{50}=$ $20.6 \mu \mathrm{g} / \mathrm{ml}$ ), which was comparable to the effect of ascorbic acid $\left(\mathrm{IC}_{50}=19.7 \mu \mathrm{g} / \mathrm{ml}\right)$. Severaler "scavenger" activity against the superoxide radical showed phytocomplexes: rudbeckia $\left(\mathrm{IC}_{50}=22.1 \mu \mathrm{g} / \mathrm{ml}\right)$ and blackberries $\left(\mathrm{IC}_{50}=21.8 \mu \mathrm{g} / \mathrm{ml}\right)$. Anti-radical activity of extracts of loosestrife, gooseberry and currant, was significantly lower 
with respect to the rest of the studied objects.The $\mathrm{IC}_{50}$ value for the loosestrife extract was $33.7 \mu \mathrm{g} / \mathrm{ml}$, the currant $32.2 \mu \mathrm{g} / \mathrm{ml}$, the gooseberry $47.2 \mu \mathrm{g} / \mathrm{ml}$. The marigold extract did't show a significant superoxide radical of antiradical activity. It should be noted that the growth of scavenging activity was "hyperbolic" in nature and the maximum superoxide-inhibiting capacity for all studied objects was noted at a concentration of $1000 \mu \mathrm{g} / \mathrm{ml}$.

The most expressed nitrosyl radical inhibitory properties showed mulberry extracts $\left(\mathrm{IC}_{50}=137.9 \mu \mathrm{g} / \mathrm{ml}\right)$, walnut $\left(\mathrm{IC}_{50}=215.8 \mu \mathrm{g} / \mathrm{ml}\right)$, currants $\left(\mathrm{IC}_{50}=217.1 \mu \mathrm{g} / \mathrm{ml}\right)$ of gooseberry $\left(\mathrm{IC}_{50}=231,4 \mu \mathrm{g} / \mathrm{ml}\right)$ and pumpkin $\left(\mathrm{IC}_{50}=\right.$ $261.2 \mu \mathrm{g} / \mathrm{ml})$. The $\mathrm{IC}_{50}$ value for these extracts was less than that of the referent - ascorbic acid $\left(\mathrm{IC}_{50}=316.4 \mu \mathrm{g} /\right.$ $\mathrm{ml})$. The extract of rudbeckia $\left(\mathrm{IC}_{50}=373.9 \mu \mathrm{g} / \mathrm{ml}\right)$ was slightly inferior to nitrosyl-antiradical activity of ascorbic acid, whereas the studied objects isolated from loosestrife, blackberry and marigolds were characterized by low nitrosyl radical scavenging ability (Fig. 2). In this case, the dependence "object concentration-inhibitory capacity" for the extracts studied was almost linear (Fig. 2).

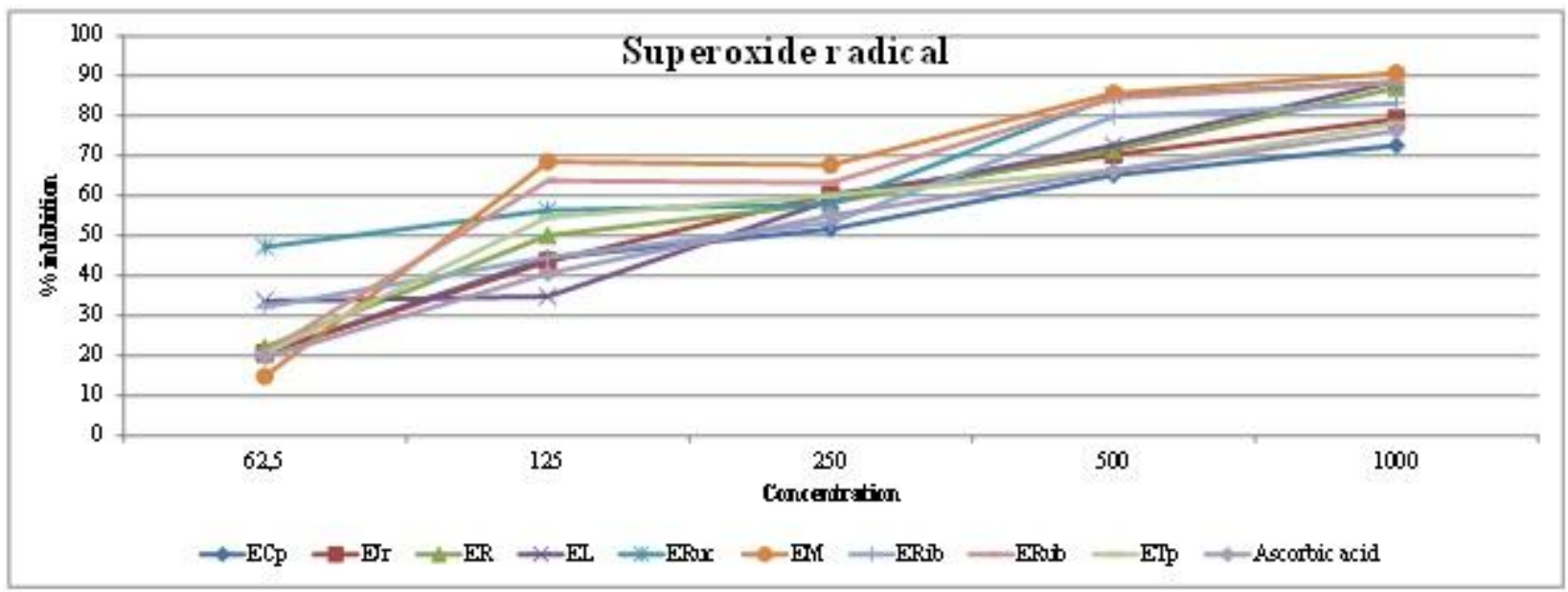

Figure 1:-Superoxide radical scavenger properties of the test extracts.

The most expressed nitrosyl radical inhibitory properties showed mulberry extracts $\left(\mathrm{IC}_{50}=137.9 \mu \mathrm{g} / \mathrm{ml}\right.$ ), walnut $\left(\mathrm{IC}_{50}=215.8 \mu \mathrm{g} / \mathrm{ml}\right)$, currants $\left(\mathrm{IC}_{50}=217.1 \mu \mathrm{g} / \mathrm{ml}\right)$, gooseberry $\left(\mathrm{IC}_{50}=231,4 \mu \mathrm{g} / \mathrm{ml}\right)$ and pumpkin $\left(\mathrm{IC}_{50}=261.2\right.$ $\mu \mathrm{g} / \mathrm{ml})$. The $\mathrm{IC}_{50}$ value for these extracts was less than that of the referent - ascorbic acid $\left(\mathrm{IC}_{50}=316.4 \mu \mathrm{g} / \mathrm{ml}\right)$. The extract of rudbeckia $\left(\mathrm{IC}_{50}=373.9 \mu \mathrm{g} / \mathrm{ml}\right)$ was slightly inferior to nitrosyl-antiradical activity of ascorbic acid, whereas the studied objects isolated from loosestrife, blackberry and marigolds were characterized by low nitrosyl radical scavenging ability (Fig. 2). In this case, the dependence «concentration-inhibitory capacity» for the extracts studied was almost linear (Fig. 2).

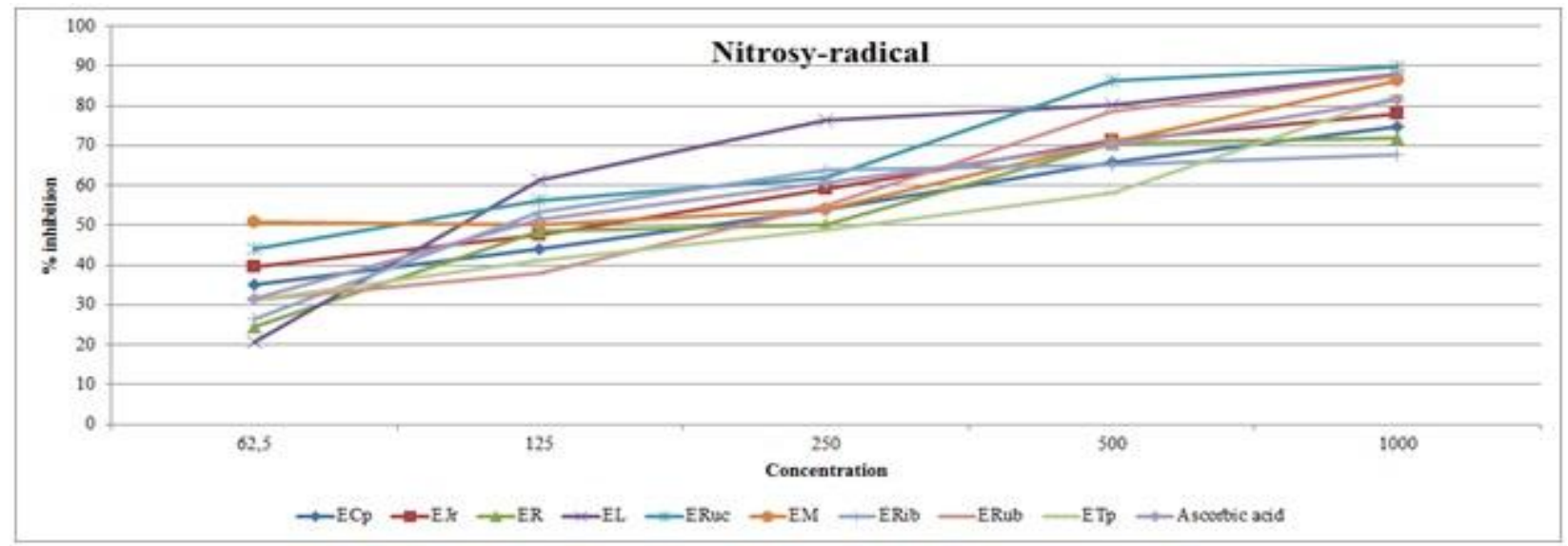

Figure 2:-Nitrosyl radical scavenger properties of the test extracts. 
For pumpkin and walnut extracts, expressed hydroxyl-radical scavenging properties (Fig. 3) were investigated, exceeding those of ascorbic acid. The $\mathrm{IC}_{50}$ value for these objects was $250.5 \mu \mathrm{g} / \mathrm{ml} ; 320.2 \mu \mathrm{g} / \mathrm{ml}$, respectively, against $333.2 \mu \mathrm{g} / \mathrm{ml}$ in the referent. Mulberry extract $\left(\mathrm{IC}_{50}=346.5 \mu \mathrm{g} / \mathrm{ml}\right)$ was comparable in hydroxyl-radical inhibition with ascorbic acid. The remaining objects under study exhibited a weakly expressed hydroxyl-radical binding activity. For extracts of loosestrife, rudbeckia, gooseberries, currants, blackberries and marigolds, the $\mathrm{IC}_{50}$ value was $676 \mu \mathrm{g} / \mathrm{ml} ; 646.6 \mu \mathrm{g} / \mathrm{ml} ; 681.9 \mu \mathrm{g} / \mathrm{ml} ; 526.3 \mu \mathrm{g} / \mathrm{ml} ; 505.9 \mu \mathrm{g} / \mathrm{ml}$ and $678.1 \mu \mathrm{g} / \mathrm{ml}$, respectively.

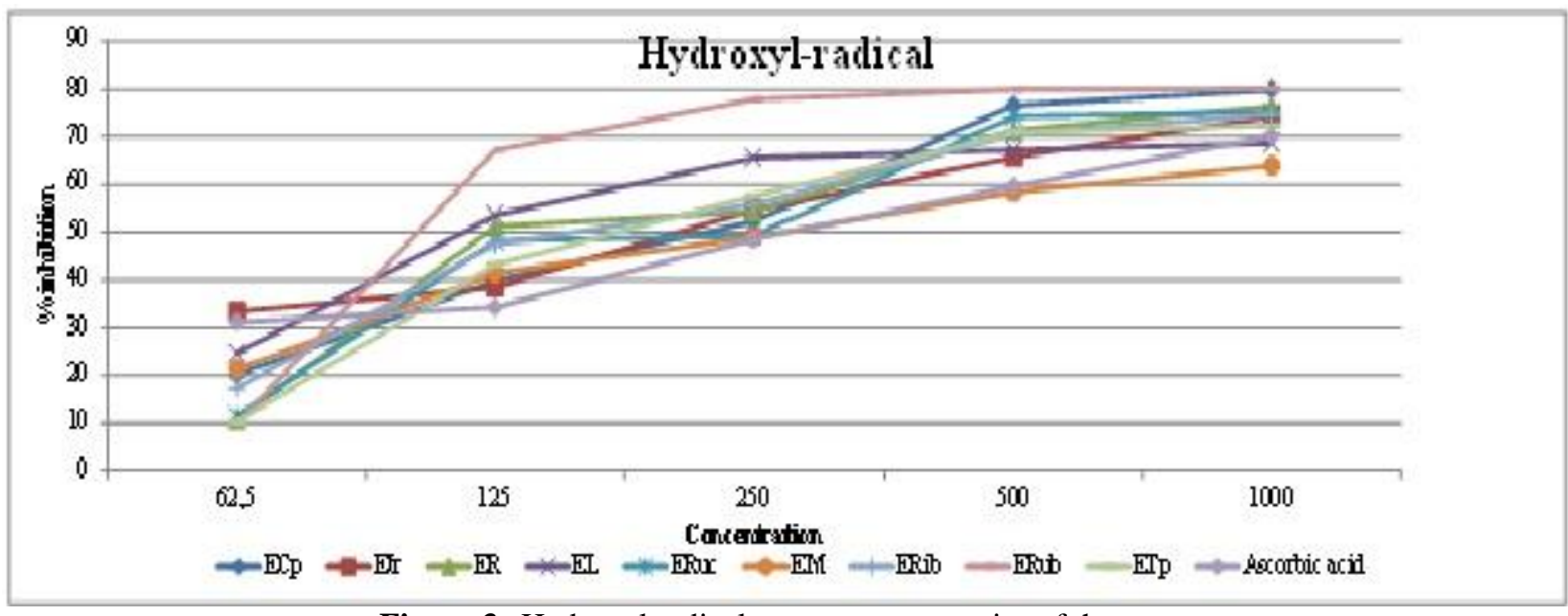

Figure 3:-Hydroxyl radical scavenger properties of the test extracts.

DPPH - inhibitory properties (Fig. 4) were established for all the studied objects. At the same time, the test extracts were superior to the referent - ascorbic acid. So the $\mathrm{IC}_{50}$ value for extracts of loosestrife, walnut, rudbeckia, pumpkin, mulberry gooseberry, currant, blackberry and marigold was $318.6 \mu \mathrm{g} / \mathrm{ml} ; 312.4 \mu \mathrm{g} / \mathrm{ml} ; 427.7 \mu \mathrm{g} / \mathrm{ml}$; $281.4 \mu \mathrm{g} / \mathrm{ml} ; 346.8 \mu \mathrm{g} / \mathrm{ml} ; 372.9 \mu \mathrm{g} / \mathrm{ml} ; 297.6 \mu \mathrm{g} / \mathrm{ml} ; 415 \mu \mathrm{g} / \mathrm{ml}$ and $418.1 \mu \mathrm{g} / \mathrm{ml}$, respectively, while in ascorbic acid this value was $463.5 \mu \mathrm{g} / \mathrm{ml}$. As can be seen, the greatest DPPH - inhibitory activity is shown by extracts of walnut and pumpkin.

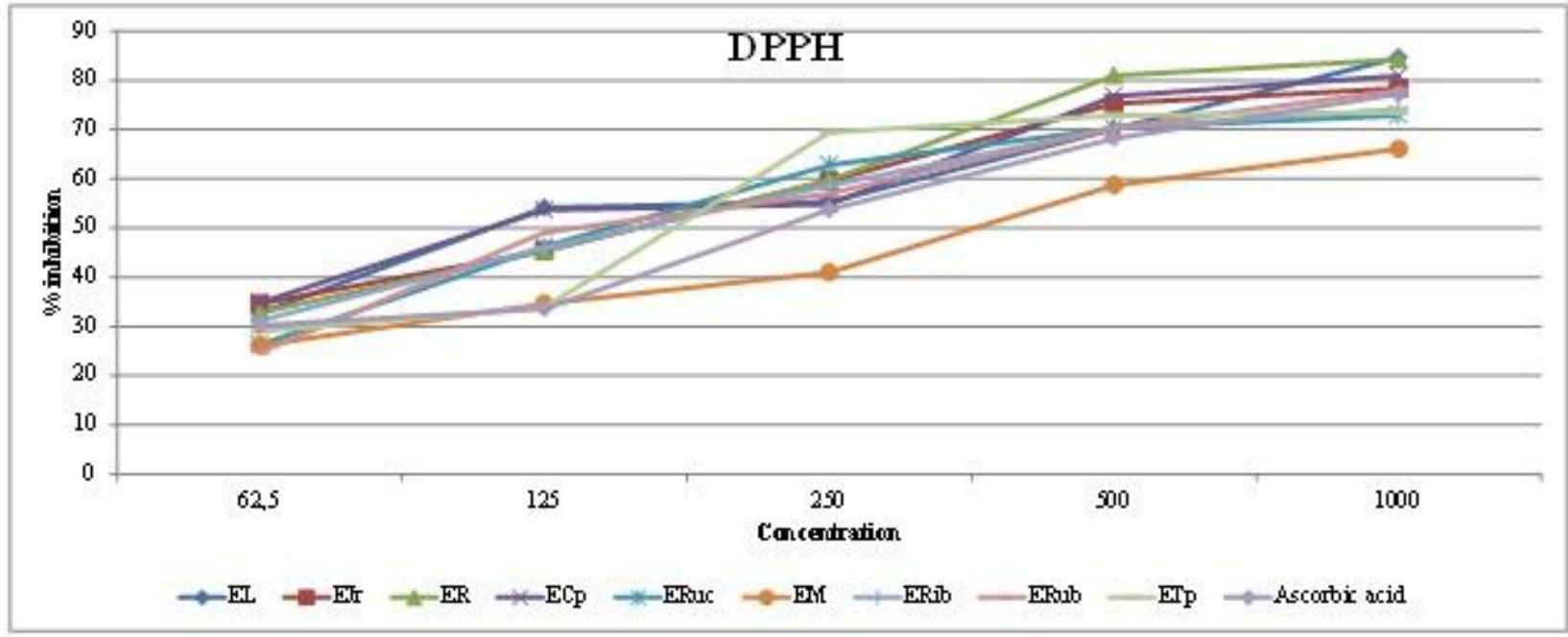

Figure 4:-DPPH-radical scavenger properties of the test extracts.

Evaluation of the iron-chelating properties of the test extracts showed that the iron-binding capacity of mulberry extracts $\left(\mathrm{IC}_{50}=191.4 \mu \mathrm{g} / \mathrm{ml}\right)$ and pumpkin $\left(\mathrm{IC}_{50}=218.6 \mu \mathrm{g} / \mathrm{ml}\right)$ was higher than that of the EDTA $\left(\mathrm{IC}_{50}=276.7\right.$ $\mu \mathrm{g} / \mathrm{ml})$. The chelating activity of walnut extracts $\left(\mathrm{IC}_{50}=262 \mu \mathrm{g} / \mathrm{ml}\right)$ and gooseberry $\left(\mathrm{IC}_{50}=248.5 \mu \mathrm{g} / \mathrm{ml}\right)$ was comparable to EDTA, the remaining studied objects were characterized by low iron-binding capacity. The $\mathrm{IC}_{50}$ value for the extracts of loosestrife, rudbeckia, currant, blackberry and marigold was $339.2 \mu \mathrm{g} / \mathrm{ml}$, respectively; 
$595.3 \mu \mathrm{g} / \mathrm{ml} ; 376.5 \mu \mathrm{g} / \mathrm{ml} ; 341.6 \mu \mathrm{g} / \mathrm{ml}$ and $330 \mu \mathrm{g} / \mathrm{ml}$. With the exception of extracts of mulberry and blackberry, the chelating activity of the evaluated objects increased almost linearly with increasing concentration of the studied object. For the extracts of mulberry and blackberry this dependence was hyperbolic (Fig. 5).

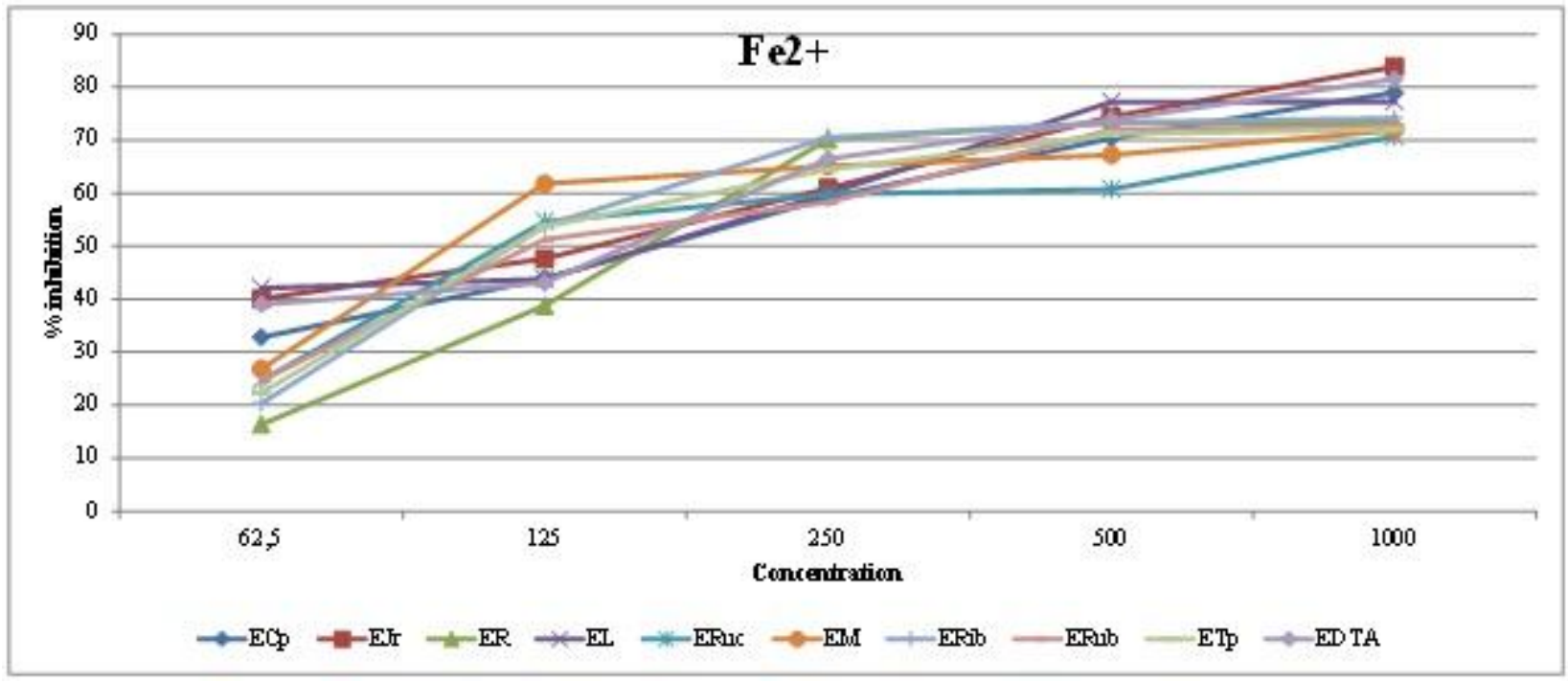

Figure 5:-Chelating activity of the test extracts.

The high antioxidant activity of the test extracts appears to be associated with a significant content of flavonoids in thestudied objects (Table 1).

Table 1:-Total content of flavonoids in test extracts

\begin{tabular}{|c|c|c|}
\hline Test extract & Standart sample & $\begin{array}{c}\text { Total flavonoids, \% } \\
\text { (M } \pm \text { SD) }\end{array}$ \\
\hline Morus alba $L$. & patuletin & $2,98 \pm 0,06$ \\
\hline Cucurbita pepo L. & quercetin & $2,11 \pm 0,277$ \\
\hline Juglans nigra $L$. & quercetin & $2,77 \pm 0,530$ \\
\hline Rudbeckia laciniata $L$. & luteolin & $0,32 \pm 0,01$ \\
\hline Tagetes patula $L$. & quercetin & $0,822 \pm 0,02$ \\
\hline Grossularia reclinata $($ L.) Mill, & quercetin & $0,51 \pm 0,01$ \\
\hline Ribes nigrum $L$. & rutin & $0,68 \pm 0,01$ \\
\hline Rubus caesius L. & rutin & $0,94 \pm 0,02$ \\
\hline Lysimachia punctata $L$. & quercetin & $0,59 \pm 0,01$ \\
\hline
\end{tabular}

\section{Discussion:-}

Free radicals are formed in cells during metabolism and perform a variety of physiological processes, such as cell proliferation, regulation of microcirculatory blood flow, apoptosis reactions, gene expression [16]. However, hyperproduction of free radicals adversely affects the condition of cells and the whole organism. The violation of the redox imbalance between the production of ROS and their inactivation by the antioxidant defense system, causes the peroxidation of membrane lipids, structural proteins, DNA, carbohydrates, enzymes, which ultimately leads to cell death [17]. In certain physiological frameworks the system of endogenous antioxidant protection is designed to reduce the negative effect of oxidants on the body. Endogenous antioxidant enzymes, such as catalase, superoxide dismutase, glutathione peroxidase, glucose-6-phosphate dehydrogenase, glutathione reductase, provide timely inactivation of ROS, which prevents their negative impact on cells [18]. At the same time, the shift of the redox status towards pro-oxidants, the inadequate activity of enzymes of endogenous antioxidant protection contribute to the development of oxidative stress, which plays a significant role in the pathogenesis of a number of diseases: cancer diabetes, cardiovascular diseases, alcoholic dystrophy of the liver, dementia, atherosclerosis, Parkinson's disease [19]. It is known that in the series of ROS the superoxide radical and its derivatives (peroxonitrite), as well as the hydroxyl radical, have the greatest cytotoxicity [20]. 
The superoxide radical, peroxonitrite and hydroxyl radical have both a direct cytotoxic effect on the cells (due to the peroxidation of the cellular structures) and mediated through activation of the cascade of apoptosis reactions and modification of protein kinase signaling pathways (Fig. 6) [21].

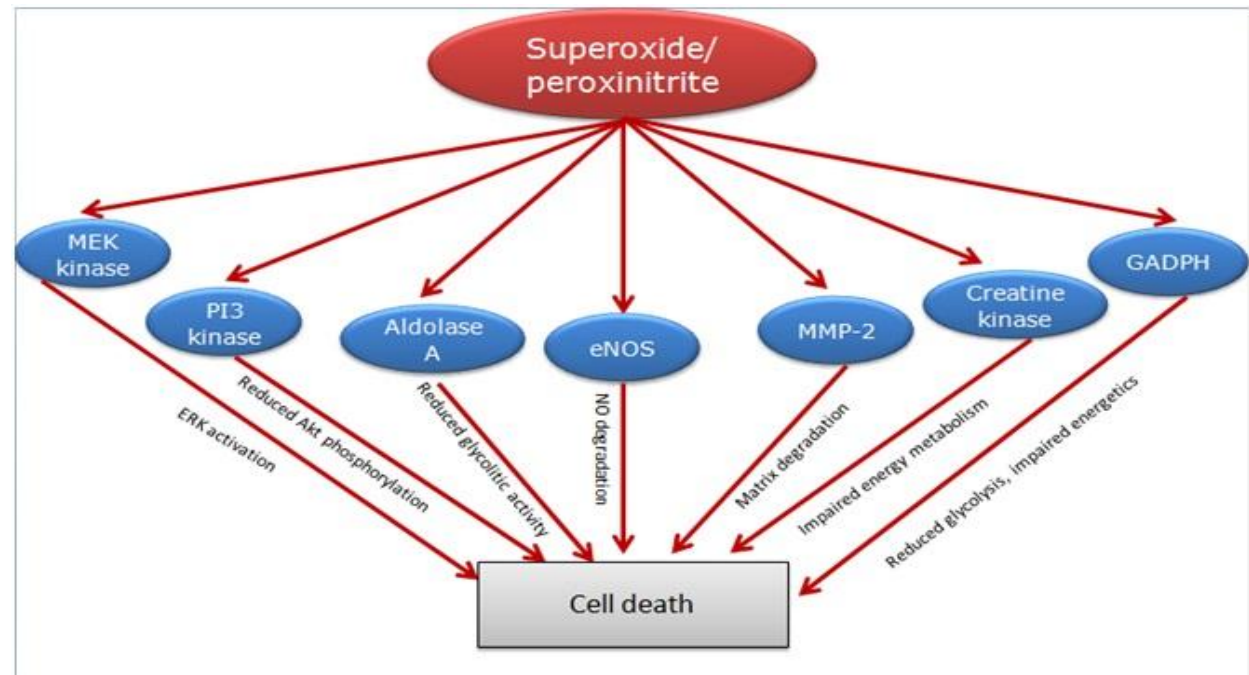

Figure 6:-ROS - mediated signaling pathways of cell death

Insufficient activity of endogenous antioxidant protection and the associated increase in the number of ROS require the appointment of exogenous antioxidants, among which are particularly allocated funds of natural origin [21]. It is known to use herbal remedies for the prevention and treatment of metabolic diseases, such as diabetes mellitus; bacterial infections, cancer, helminth infestations, inflammatory and autoimmune diseases. A wide range of pharmacological activity associated with low systemic toxicity of the administration makes objects of natural origin promising for study, in order to identify new classes of biologically active substances, as well as types of biological activity. [22].

In the course of this study, it was found that of 9 plant extracts, 3 have pronounced antioxidant properties. High antiradical activity was determing for extracts of Juglans nigra L bark, Morus alba L leaves and Cucurbita pepo L. fruitage. The obtained data in a series of in vitro tests indicate that the studied extracts of mulberry, pumpkin and walnut inhibit the generation of DPPH radical, superoxide, nitrosyl and hydroxyl radicals, and also exhibit ironchelating properties. Other studied objects: extarcts from inflorescence of Tagetes patula L, Rudbeckia laciniata L.; leaves of Grossularia reclinata (L.) Mill., Ribes nigrum L., Rubus caesius L.; herb of Lysimachia punctata L. were characterized by moderate antioxidant properties and inferior in activity to referents-ascorbic acid and EDTA.

Cucurbita pepo L. widely cultivated plant, extracts from which have: anthelmintic [23], antiatherosclerotic [24], anticarcinogenic activity [25]. Extracts from Morus alba L also have a large range of pharmacological activity, including such types as: hypoglycemic, lipid-regulating, antihypertensive [26], immunotropic action [27]. As the main active substance in the extracts obtained from Juglans nigra L the presence of juglone, characterized by cytotoxic [28] and hepatoprotective properties [29]. As can see, the leading extracts have a significant spectrum of pharmacological activity, and at the same time the high antioxidant activity of the extracts to be evaluated is probably associated with a significant content of flavonoids in their composition. It is known that flavonoids have pronounced scavenger properties due to the presence of an aromatic nucleus and conjugated multiple bonds, as well as a reactive-active proton in the $\mathrm{OH}$ group in the third position [30] and objects containing a significant amount of flavonoids exhibit pronounced antioxidant properties [31-33].

\section{Conclusion:-}

The study showed the prospects of using extracts of mulberry, pumpkin and walnut as a means of antioxidant activity. It is also advisable to further study these objects for the ability to increase the activity of enzymes of endogenous antioxidant protection. In addition, it seems relevant to separate individual extracts from these extracts and further assess their biological activity. 


\section{Acknowledgements And Funding}

This research received no specific grant from any funding agency in the public, commercial, or not-for-profit sectors.

\section{Conflicts Of Interest}

The authors statement no conflict of interest with the submitted manuscript.

\section{Abbreviations}

DPPH-2,2-diphenyl-1-picrylhydrazyl; ROS - reactive oxygen radicals; SOD - superoxide dismutase; EDTA ethylenediaminetetraacetate; ECp - pumpkin extract; EJr - walnut extract; ER - extract of rudbeckia; EL - extract of a loosestrife; ERuc - extract of gooseberries; EM - mulberry extract; ERib - extract of currant; ERub - blackberry extract; ETp - marigold extract.

\section{Summary}

1. Exogenous antioxidants help to eliminate the manifestations of oxidative stress

2. Among the studied extracts, the most pronounced antioxidant properties are the extracts from: Juglans nigra $L$ bark, Morus alba $L$ leaves and Cucurbita pepo L. fruitage.

3. The studied extracts-leaders can serve as a valuable source of antioxidant compounds

\section{References:-}

1. Veskoukis AS, Tsatsakis AM, Kouretas D. Dietary oxidative stress and antioxidant defense with an emphasis on plant extract administration. Cell St. \& Chap. 2012;17(1):11-21. doi:10.1007/s12192-011-0293-3.

2. Zhang S, Wei Z, Liu W, et al. Indicators for Environment Health Risk Assessment in the Jiangsu Province of China. Tchounwou PB, ed. Int. J. Env. Res. P.H.. 2015;12(9):11012-11024. doi:10.3390/ijerph120911012.

3. Pizzimenti S, Toaldo C, Pettazzoni P, Dianzani M, Barrera G. The "Two-Faced" Effects of Reactive Oxygen Species and the Lipid Peroxidation Product 4-Hydroxynonenal in the Hallmarks of Cancer. Cancers. 2010;2:338-363. doi: 10.3390/cancers2020338.

4. Halliwell B, Gutteridge JMC. Free radicals in biology and medicine. 4. Oxford: Clarendon; 2007.

5. Pickering RJ, Rosado CJ, Sharma A, Buksh S, Tate M, de Haan JB. Recent novel approaches to limit oxidative stress and inflammation in diabetic complications. Clin. \& Trans.Imm. 2018;7(4):e1016. doi:10.1002/cti2.1016.

6. Fang Y, Yang S, Wu G. Free radicals, antioxidants, and nutrition.Nutr.2002;18:872-879.doi: 10.1016/S08999007(02)00916-4.

7. Mishra A, Sharma AK, Kumar S, Saxena AK, Pandey AK. Bauhinia variegataLeaf Extracts Exhibit Considerable Antibacterial, Antioxidant, and Anticancer Activities. BioMed Res. Inter. 2013;2013:915436. doi:10.1155/2013/915436.

8. WHO: International Agency for Research on Cancer . IARC monographs on the evaluation of carcinogenic risks to humans. Volume 82. Some traditional herbal medicines, some mycotoxins, naphthalene and styrene. Lyon: IARC Press; 2002.

9. Choumessi A, Danel M, Chassaing S, Truchet I, Penlap V, Pieme A, et al. Characterization of the antiproliferative activity of Xylopia aethiopica. Cell Div. 2012;7:8. doi: 10.1186/1747-1028-7-8.

10. Mensor LL, Menezes FS, Leitão GG, Reis AS, dos Santos TC, Coube CS, et al. Screening of Brazilian plant extracts for antioxidant activity by the use of DPPH free radical method. Phytother Res. 2001;15:127-30.

11. Elizabeth K, Rao MN. Oxygen radical scavenging activity of curcumin.Int J Pharm.1990;58:237-40.

12. Winterbourn CC, Hawkins RE, Brian M, Carrell RW.The estimation of red cell superoxide dismutase activity.J Lab Clin Med.1975;85:337-41.

13. Marcocci L, Maguire JJ, Droy-Lefaix MT, Packer L. The nitric oxide-scavenging properties of Ginkgo biloba extract EGb 761.Biochem Biophys Res Commun.1994;201:748-55.

14. Benzie IF, Strain JJ. The ferric reducing ability of plasma (FRAP) as a measure of "antioxidant power": The FRAP assay. Anal Biochem. 1996;239:70-6.

15. Garg D, Shaikh A, Muley A, Marar T. In vitro antioxidant activity and phytochemical analysis in extracts of Hibiscus rosa-sinensis stem and leaves. Free Radic Antioxid. 2012;2:41-6.

16. Pisoschi AM, Pop A, Cimpeanu C, Predoi G. Antioxidant Capacity Determination in Plants and Plant-Derived Products: A Review. Ox. Med. and Cell.Long. 2016;2016:9130976. doi:10.1155/2016/9130976.

17. Poljsak B., Šuput D., Milisav I. Achieving the balance between ROS and antioxidants: when to use the synthetic antioxidants. Ox. Med. and Cell.Long. 2013;2013:11. doi: 10.1155/2013/956792.956792. 
18. Gupta D. Methods for determination of antioxidant capacity, a review. Int. J.of Pharm. Sc. and Res. 2015;6:546-566.

19. Fukai T, Ushio-Fukai M. Superoxide Dismutases: Role in Redox Signaling, Vascular Function, and Diseases. Antiox. \& Red. Sign. 2011;15(6):1583-1606. doi:10.1089/ars.2011.3999.

20. Pacher P, Beckman JS, Liaudet L. Nitric Oxide and Peroxynitrite in Health and Disease. Physiol. rev. 2007;87(1):315-424. doi:10.1152/physrev.00029.2006.

21. Gul MZ, Bhakshu LM, Ahmad F, Kondapi AK, Qureshi IA, Ghazi IA. Evaluation of Abelmoschus moschatus extracts for antioxidant, free radical scavenging, antimicrobial and antiproliferative activities using in vitro assays. BMC Compl. and Alter. Med. 2011;11:64. doi:10.1186/1472-6882-11-64.

22. Lulan TYK, Fatmawati S, Santoso M, Ersam T. Antioxidant Capacity of Some Selected Medicinal Plants in East Nusa Tenggara, Indonesia: The Potential of Sterculia quadrifida R.Br. Free Rad. and Antiox.. 2018;8(2):96-101.

23. Grzybek M, Kukula-Koch W, Strachecka A, Jaworska A, Phiri AM, Paleolog J, Tomczuk K. Evaluation of Anthelmintic Activity and Composition of Pumpkin (Cucurbita pepo L.) Seed Extracts-In Vitro and in Vivo Studies. Int.J.of Mol.Sc. 2016; 17(9):1456.

24. Al-Zuhair H, Abdel-Fattah A A, Abd el Latif H A. Efficacy of simvastatin and pumpkin-seed oil in the management of dietary-induced hypercholesterolemia. Pharmacol Res. 1997;35:403-408.

25. Huang XE, Hirose K, Wakai K, Matsuo K, Ito H, Xiang J. Comparison of lifestyle risk factors by family history for gastric, breast, lung and colorectal cancer. APJCP. 2004;5:419-427.

26. El-Sayyad, H I H \& El-Sherbiny, M A \& Sobh, M A \& Abou-El-Naga, A M \& Ibrahim, M A N \& Mousa, S A. Protective effects of Morus alba leaves extract on ocular functions of pups from diabetic and hypercholesterolemic mother rats. Int J Biol Sci. 2011; 7(6): 715-728.

27. Kim SB, Chang BY, Jo YH, Lee SH, Han SB, Hwang BY, et al. Macrophage activating activity of pyrrole alkaloids from Morus alba fruits. J Ethnopharmacol 2013; 145(1): 393-6. doi: 10.1016/j.jep.2012.11.007.

28. Liu L, Li W, Koike K, Zhang S, Nikaido T. Newalpha-tetralonylglucosides from the fruit of Juglans mandshurica. Chem Pharm Bull Tokyo. 2004;52:566-569. doi: 10.1248/cpb.52.566

29. Zhou, D., Mu, D., Jiang, M., Zheng, S., Zhang, Y., He, S., Weng, M., Zeng, W."Hepatoprotective effect of juglone on dimethylnitrosamine-induced liver fibrosis and its effect on hepatic antioxidant defence and the expression levels of $\alpha$-SMA and collagen III". Mol Med Rep. 2015 Sep; 12(3): 4095-4102. doi: 10.3892/mmr.2015.3992

30. Kumar S, Pandey AK. Chemistry and Biological Activities of Flavonoids: An Overview. The Scien.W. J. 2013;2013:162750. doi:10.1155/2013/162750.

31. Mushtaq A, Masoodi MHussain, Wali AFarooq, Ganai BAhmad. Total Phenolic Content, Total Flavonoid Content, In vitro Antioxidant Activity and Antimicrobial Activity against Human Pathogenic Bacteria of Eremurus Himalaicus-An Edible Herb of North Western Himalayas. Free Rad. and Antiox. 2017;7(1):90-94

32. Pirzadah TBilal, Malik B, Tahir I, Qureshi MIrfan, Rehman RUl. Metabolite Fingerprinting and Antioxidant Potential of Tartary Buckwheat- an Underutilized Pseudocereal crop from Kashmir Region. Free Rad. and Antiox. 2017;7(1):95-106.

33. Bhat MYasin, Gul MZahoor, Lohamror LRam, Qureshi IAhmed, Ghazi IAhmad. An in vitro Study of the Antioxidant and Antiproliferative Properties of Artemisia absinthium- A Potent Medicinal Plant. Free Rad. and Antiox. 2018;8(1):18-25. 